\title{
VERONICO BECCABUNGAE-CALLITRICHETUM STAGNALIS (OBERD. 1957) MÜLLER 1962, A PLANT ASSOCIATION NEW TO POLAND - QUALITY OF HABITAT
}

\author{
KRZYSZTOF SPAŁEK ${ }^{1}$, SYlWIA HORSKA-SCHWARZ ${ }^{2}$ \\ ${ }^{1}$ Laboratory of Geobotany and Plant Conservation, \\ Department of Biosystematics University of Opole \\ Oleska 22, 45-052 Opole, Poland \\ e-mail: kspalek@uni.opole.pl \\ ${ }^{2}$ Institute of Geography and Regional Development University of Wrocław \\ Pl. Uniwersytecki 1, 50-137 Wrocław, Poland
}

(Received: April 23, 2009. Accepted: July 22, 2009)

\begin{abstract}
The paper presents a community of water plants that is new to Poland, Veronico beccabungae-Callitrichetum stagnalis (Oberd. 1957) Müller 1962. This community belongs to the class Potametea. It was discovered in the village of Odrowąż near the town of Krapkowice in Silesia (SW Poland). Veronico beccabungae-Callitrichetum stagnalis in Poland occurs within an irregularly shaped shallow underwater spring, located in the distal part of the Oder River's flood terrace. This plant community covered 0.2 ha in 2008. Callitriche stagnalis predominated in this community. Species such as Callitriche hamulata and Callitriche verna occurred less frequently. An average of five species were counted in a relevé. Alkaline sediments $(\mathrm{pH} \mathrm{8.03)} \mathrm{occur} \mathrm{in} \mathrm{the} \mathrm{substratum,} \mathrm{but} \mathrm{sediments}$ with a lower $\mathrm{pH}$ value (7.73) occur in the spring's outflow zone towards the Odra River. Water in the spring, where Veronico beccabungae-Callitrichetum stagnalis occurred, has a medium mineralisation but is rich in dissolved compounds. The condition of this community within the studied habitat could be evidence for highly adaptive abilities and this community's good adjustment to the natural conditions. Veronico beccabungae-Callitrichetum stagnalis is a rare and endangered plant community in Central Europe. The locality of this plant community in Poland should be given species protection.
\end{abstract}

KEY WORDS: Veronico beccabungae-Callitrichetum stagnalis, Potametea class, distribution, phytosociology, Poland, endangered association, quality of habitat.

\section{INTRODUCTION}

Veronico beccabungae-Callitrichetum stagnalis (Oberd. 1957) Müller 1962 was first recognized in higher elevation of the southern Schwartzwald, Germany, in clean, cold and fast-running rivers poor in calcium carbonate (Oberdorfer 1957). It was later found in other regions of Germany (Müller 1962; Grube 1975; Müller, Görs 1977; MonschauDudenhausen 1982; Pietsch 1983; Dersch 1986; Schwabe 1987; Pott 1980, 1983, 1990, 1995; Passarge 1996; Gutowski et al. 1998; Wolff 1999), in France (Haury, Muller 1991) and in Great Britain (Rodwell 2000). This community occurs in shallow $(30-80 \mathrm{~cm})$, oligotrophic, cold, clearrunning or stagnating waters poor in calcium carbonate, in rivers, ditches or springs with a bottom of sand or silt (Oberdorfer 1957, Müller 1962; Grube 1975; MonschauDudenhausen 1982; Pietsch 1983; Schwabe 1987; Pott 1980, 1983, 1990, 1995; Passarge 1996; Gutowski et al. 1998; Haury and Muller 1991; Wolff 1999). The typical and dominant species of this plant community is Callitriche stagnalis and Veronica beccabunga form submersa. Callitriche stagnalis was observed mostly in southern and western Poland (Pawłowski 1956; Zając and Zając 2001). The highest concentrations of this species were recorded in Lower Silesia and in Western Pomerania (Pawłowski 1956). Most records of this species come from the turn of 19th and 20th centuries (Pawłowski 1956), so most should be considered as historical records. After 1945 this species was observed far less frequently. The composition of this plant community varies. So far, three of its subassociations have been distinguished: Veronico beccabungae-Callitrichetum stagnalis typicum, Veronico beccabungae-Callitrichetum stagnalis potamogetonetosum and Veronico beccabungae-Callitrichetum stagnalis stellarietosum (Pietsch 1983; Passarge 1996). This association is considered to be poor in species and usually consists of 1-15 taxa (Pietsch 1983; Passarge 1996; Pott 1990; Wolff 1999). Phytocoenoses of this plant community have not yet been described in 
Poland. This aquatic plant community is endangered at both a regional and a Central European scale (Pott 1995; Rennwald 2000).

Poor condition of the natural environment (as a result of human activity) requires a detailed identification of processes, phenomena and characteristics of these components which determine the increased susceptibility to stress. The level of deformation of the landscape normally is determined on the basis of the selected ,ecological indicator" (Hunsaker 1993, Dale and Beyeler 2001; Schiller et al. 2001). For the purpose of assessing the quality of the environment, plants are used often (Schwabe 1989; BalsbergPahlsson 1989; Burrows 1990; Shaw and Albright 1990; Grodzinska and Godzik 1991), but also water (Zerbe et al. 1994). In this case, for quantitatively assessing the quality of a habitat heavy metals were used (such as $\mathrm{Cd}, \mathrm{Pb}, \mathrm{Cu}$, $\mathrm{Zn}, \mathrm{Ni}, \mathrm{Al}$ and $\mathrm{Mn}$ ), large concentrations of which in the waters, sediments and plants may indicate contamination.

Physical and chemical properties of the soil, and quality, general mineralisation and physical properties of water are the main factors for the proper development of aquatic plant communities. It is generally assumed that the choice of habitat depends mainly on the ecological amplitude of a plant community. It therefore seems, desirable to study ecosystems at the level of microhabitats to identify factors that limit the development or the range of plant communities. Given that the quality of microhabitats, especially in aquatic environments, changes easily under heavy human pressure, it might be assumed that in most cases the factors limiting the occurrence of certain species would be for example: pollution, a change in the chemical content of the water, lower $\mathrm{pH}$, higher water salinity, less of dissolved oxygen in water, more nutrients and the eutrophication of waters, or a decrease in habitat richness (Horska-Schwarz and Spałek 2008).

This paper describes the community of Veronico beccabungae-Callitrichetum stagnalis. The study provides the phytosociological table and the floristic composition, and it discusses the ecological requirements of this community. The assessment of the main, relatively constant habitat features should allow researchers to asses the adaptive ability of this community to environmental conditions. The obtained results will form the basis for the protection of this community, mainly by identifying the main threats resulting from the location, the environmental conditions and the increasing human pressure. Many plant communities have strict preferences for the $\mathrm{pH}$ of the habitat, because an alkaline reaction significantly restricts the absorption of nutrients and an acid reaction determines mobility and thus the accessibility of nutrients.

\section{METHODS}

The fieldwork was conducted during the growth seasons in 2005-2008. Veronico beccabungae-Callitrichetum stagnalis community was studied with the methods of the $\mathrm{Zu}$ rich-Montpellier School of Phytosociology (Braun-Blanquet 1964). The phytosociological nomenclature and the syntaxonomical appendix are based on Oberdorfer (1994) and Matuszkiewicz (2005). The species names of vascular plants are given according to Mirek et al. (2002). The assessment of the physical and chemical properties of the ha- bitat was determined in the fieldwork, when the $\mathrm{pH}$ of water was measured in the spring at depths of $0-20 \mathrm{~cm}$ and $20-40 \mathrm{~cm}$, and in the zone of the outflow to the Odra River at a depth of 0-20 cm. Measurements of conductivity, temperature of water and the $\mathrm{O}_{2}$ content of the water were taken at the depth of $0-20 \mathrm{~cm}$ at the spring and at the zone of its outflow to the river with a CX 401 Elmetron multipurpose measuring device. Samples of water at a depth of 0 $20 \mathrm{~cm}$ and samples of the bottom sediments were collected from the spring and from the outflow to the Odra River. Laboratory tests consisted in: analysis of water, which included measurement of the $\mathrm{CO}_{2}$ content $\left[\mathrm{mg} / \mathrm{dm}^{3}\right]$, general alkalinity (measured by titration), $\mathrm{SO}_{4}{ }^{2-}\left[\mathrm{mg} / \mathrm{dm}^{3}\right]$ (measured by the turbidimetric method), $\mathrm{NO}_{3}{ }^{-}, \mathrm{Cl}^{-}, \mathrm{NH}_{4}^{+}, \mathrm{PO}_{4}{ }^{3-}-$ $\left[\mathrm{mg} / \mathrm{dm}^{3}\right]$ (measured by the colorimetric method with a Slandi LF 2004 spectrophotometer), and an analysis of the bottom sediments, which included the identification of $\mathrm{pH}$ in the water extract (measured by the potentiometric method used in soil sciences) and the $\mathrm{CaCO}_{3}$ content $\left[\mathrm{mg} / \mathrm{dm}^{3}\right]$ (measured by the calicimeter - pressure method).

\section{RESULTS}

During geobotanical research conducted in south-western Poland one site of Veronico beccabungae-Callitrichetum stagnalis was discovered in a spring in the village Odrowąż near the town of Krapkowice in Silesia (SW Poland) (Fig. 1). This plant community covered 0.2 ha in 2008. Callitriche stagnalis predominated in this community (Table 1). Species such as Callitriche hamulata and Callitriche verna occurred less frequently. An average of five species were counted in a relevé. The total number of species found in the studied patches of Veronico beccabungaeCallitrichetum stagnalis in Poland was 11, which is close to the number of species in this community in similar waters in Germany (Grube 1975; Monschau-Dudenhausen 1982; Schwabe 1987; Pott 1990; Passarge 1996; Wolff 1999). Patches of this community should be assigned to the subcommunity Veronico beccabungae-Callitrichetum stagnalis typicum (Pietsch 1983; Passarge 1996). In phytocoenoses

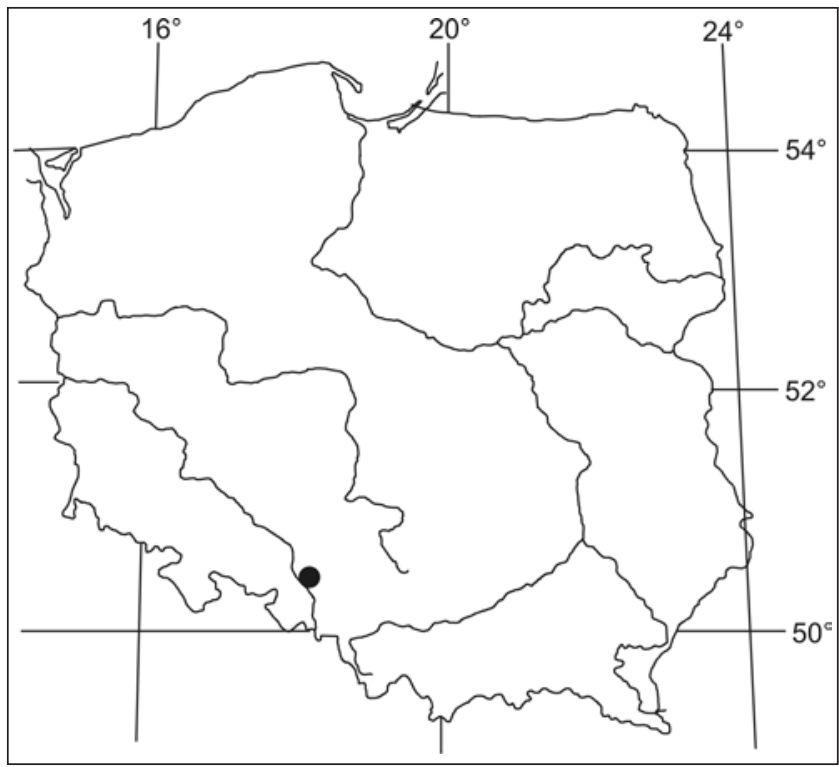

Fig. 1. Locality of Veronico beccabungae-Callitrichetum stagnalis in Poland. 
TABLE 1. Veronico beccabungae-Callitrichetum stagnalis (Oberd. 1957) Müller 1962.

\begin{tabular}{|c|c|c|c|c|c|c|c|c|c|c|c|}
\hline Relevé number & 1 & 2 & 3 & 4 & 5 & 6 & 7 & 8 & 9 & 10 & $\mathrm{C}$ \\
\hline Date: year & 2005 & 2005 & 2005 & 2006 & 2006 & 2006 & 2008 & 2008 & 2008 & 2008 & \\
\hline month & 07 & 07 & 07 & 08 & 08 & 08 & 08 & 08 & 08 & 08 & \\
\hline day & 20 & 20 & 20 & 06 & 06 & 06 & 11 & 11 & 11 & 11 & \\
\hline Cover of herb layer [\%] & 70 & 65 & 80 & 80 & 75 & 70 & 70 & 85 & 75 & 75 & \\
\hline Area of relevé $\left[\mathrm{m}^{2}\right]$ & 8 & 10 & 10 & 10 & 8 & 8 & 10 & 10 & 8 & 10 & \\
\hline Number of species in relevé & 6 & 5 & 6 & 4 & 3 & 7 & 4 & 3 & 8 & 7 & \\
\hline Ch. Veronico beccabungae-Callitrichetum stagnalis & 4 & 4 & 4 & 4 & 4 & 4 & 4 & 4 & 4 & 4 & $\mathrm{~V}$ \\
\hline $\begin{array}{l}\text { Callitriche stagnalis } \\
\text { Veronica beccabunga form submersa }\end{array}$ & . & + & + & . & . & + & . & . & 1 & . & II \\
\hline Ch. Ranunculion fluitantis & 1 & 1 & 2 & 1 & + & 1 & 1 & 2 & 2 & + & $\mathrm{V}$ \\
\hline $\begin{array}{l}\text { Callitriche hamulata } \\
\text { Berula erecta form submersa }\end{array}$ & . & . & + & . & + & + & . & . & . & + & II \\
\hline Ch. Potametea & + & 1 & + & + & . & + & 1 & + & . & + & IV \\
\hline Callitriche verna & + & + & . & . & . & + & . & . & + & . & II \\
\hline $\begin{array}{l}\text { Elodea canadensis } \\
\text { Myriophyllum verticillatum }\end{array}$ & . & . & . & . & . & . & . & . & + & + & I \\
\hline Ch. Lemnetea minoris & + & . & . & . & . & + & + & . & . & + & II \\
\hline $\begin{array}{l}\text { Lemna minor } \\
\text { Spirodela polyrhiza }\end{array}$ & + & . & . & . & . & . & . & . & + & . & I \\
\hline Ch. Phragmitetea & . & . & . & + & . & . & . & . & + & + & II \\
\hline $\begin{array}{l}\text { Glyceria maxima. } \\
\text { Phragmites australis }\end{array}$ & . & . & + & . & . & . & . & . & + & . & I \\
\hline
\end{tabular}

Explanation: Ch. - characteristic species; C - constancy

of this association in Poland, in contrast to the patches of this community in Germany, we did not find Stellaria uliginosa and Batrachium hederaceum, which probably do not occur in Poland (Mirek et al. 2002). As in the phytocoenosis described in Germany (Grube 1975; Monschau-Dudenhausen 1982; Schwabe 1987; Pott 1990; Passarge 1996; Wolff 1999), the segments of Veronico beccabungae-Callitrichetum stagnalis in Poland had a distinct two-layered structure. Callitriche stagnalis with a smaller quantity of Callitriche hamulata, Veronica beccabunga form submersa and Berula erecta form submersa dominated the underwater layer. The layer above the waterline was formed by Lemna minor with some Spirodela polyrhiza and Myriophyllum verticillatum.

Veronico beccabungae-Callitrichetum stagnalis occurs in Poland within an irregularly shaped shallow underwater spring, located in the distal part of the Odra River's flood terrace. The zone of outflow of underground waters, which can be classified as the type of occurring at the edge of the valley, that lays in the direct zone of flood waters (Staśko 1984). Alkaline sediments ( $\mathrm{pH} 8.03$ ) occur in the substratum, but sediments with a lower $\mathrm{pH}$ value (7.73) occur in the spring's outflow zone towards the Odra River. This substratum's reaction shows that the nutrients have a limited mobility. Laboratory analyses showed that the bottom sediments in the spring zone were abundant in: calcium (44038.45 ppmCa/kg), iron (5843.50 ppmFe/kg), aluminium (3400.5 ppmAl/kg) and magnesium (1138 ppm $\mathrm{Mg} / \mathrm{kg}$ ). The remaining compounds occurred in smaller concentrations, below $1 \mathrm{~g} / \mathrm{kg}(\mathrm{K}>\mathrm{Zn}>\mathrm{Na}>\mathrm{Pb}>\mathrm{Ni}>\mathrm{Cu}>\mathrm{Cd})$.

We found the waters were mineralised at a level of 750 $\mathrm{mg} / \mathrm{dm}^{3}$, which was higher than found during studies conducted in 1978-1983 (Staśko 1984). The water we analysed showed a slightly alkaline reaction, with $\mathrm{pH}$ varying 7.16 in the spring to 7.2 in the outflow zone. These waters were well oxygenated and the dissolved oxygen was relatively high, at $12.8 \mathrm{mg} \mathrm{O}_{2} / \mathrm{dm}^{3}$ around the spring, but lower in the outflow zone, at $8.27 \mathrm{mg} \mathrm{O} / \mathrm{dm}^{3}$. In field studies on $8 \mathrm{Fe}$ bruary 2008 the water temperature around the spring (at the depths $0-20 \mathrm{~cm}$ and $20-40 \mathrm{~cm})$ was $9.6^{\circ} \mathrm{C}$, but $9.7^{\circ} \mathrm{C}(0-20$ $\mathrm{cm}$ under the water level) in the outflow zone. The literature (Staśko 1984, 1992) suggests a relatively low range of changes in the water temperature in the spring of about $1^{\circ} \mathrm{C}$. The temperatures ranged from $9.4^{\circ} \mathrm{C}$ to $10.4^{\circ} \mathrm{C}$ ).

Water in the spring where Veronico beccabungae-Callitrichetum stagnalis occurred has a medium mineralisation but is rich in dissolved compounds. It contains significant concentrations of macroelements, especially of calcium (93.85 mgCa/dm ${ }^{3}$ ) magnesium (19.41 mg Mg/dm ${ }^{3}$ ), sodium $\left(8.01 \mathrm{mgNa} / \mathrm{dm}^{3}\right)$ and potassium $\left(1.24 \mathrm{mgK} / \mathrm{dm}^{3}\right)$. The remaining elements, such as: aluminium, iron, copper, zinc, lead, nickel and cadmium occurred in trace quantities (Table 2). Our studies showed that the outflowing water had a similar chemical composition as the water around the spring, but they are slightly enriched in nutrients: nitrates, phosphates and ammonia. A small increase in the indices of salinity, such as the content of sulphates and chlorides, was also noted.

The condition of Veronico beccabungae-Callitrichetum stagnalis within the studied habitat could constitute a proof of highly adaptive abilities and that community's good adjustment to natural conditions. Our studies showed that the water habitat undergoes relatively small changes in its main physical and chemical parameters. The chemical composition was similar to those found in earlier studies of the water at this spring (Staśko 1984, 1992). The concentrations of $\mathrm{Cl}, \mathrm{Mg}$, and $\mathrm{Ca}$ that we found were in the same range of values, $\mathrm{Na}$ and $\mathrm{K}$ had slightly higher concentra- 


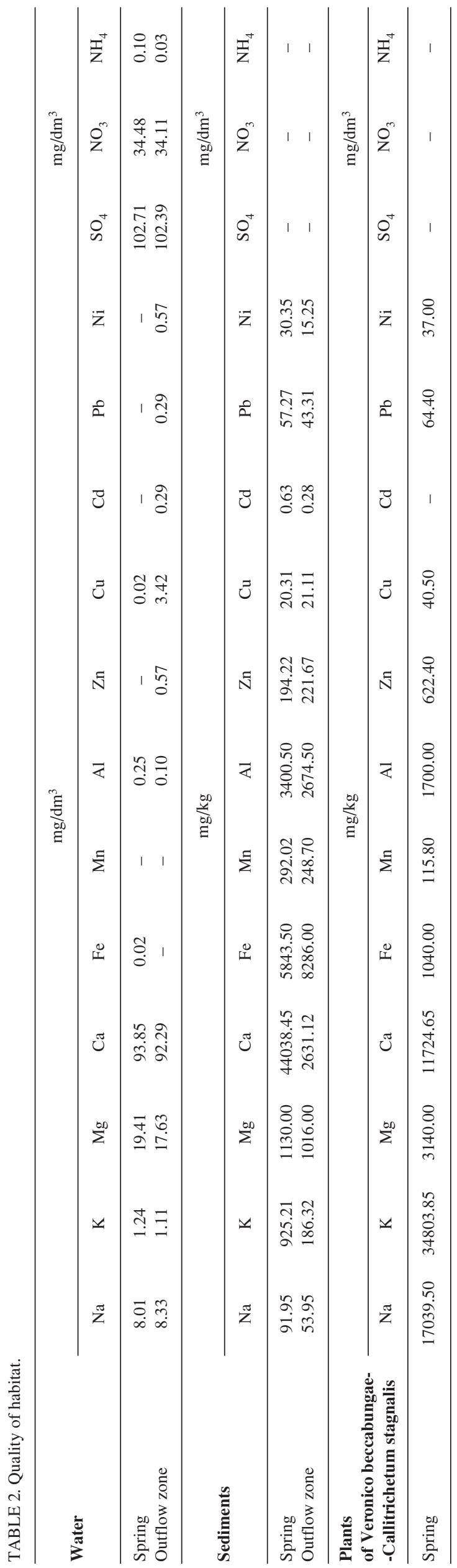

tions - the increase was at the level of $1 \%$ mval, but the greatest difference were recorded in the concentration of $\mathrm{SO}_{4}$ in the tested water - the increase was more than $20 \%$ mval. It also seems that physical properties of water $-\mathrm{pH}$ and temperature, which have remained constant for more than 24 years, are important for the proper development of Veronico beccabungae-Callitrichetum stagnalis.

The richness of the habitat and the chemical properties of the water indicate that this community requires relatively high concentrations of nutrients. We assume that an acid reaction in the water and substrate, lower habitat richness or larger variation of the physical and chemical parameters would have led to a different development pattern of Veronico beccabungae-Callitrichetum stagnalis. Therefore the factor limiting the range and proper development of this community could be radically changed of the physical and chemical properties of the habitat.

The locality of Veronico beccabungae-Callitrichetum stagnalis in Poland should be given species protection. The complete phytosociological and habitat characteristics and the present distribution of Veronico beccabungae-Callitrichetum stagnalis in Poland should be the subject of further botanical investigations, because this association is probably more widespread than has yet been found.

\section{SYSTEMATICAL POSITION OF THE COMMUNITY}

Class: Potametea R. Tx. et Prsg. 1942

Order: Potametalia Koch 1926

Alliance: Ranunculion fluitantis Neuhäusl 1959

Association: Veronico beccabungae-Callitrichetum stagnalis (Oberd. 1957) Müller 1962

\section{ACKNOWLEDGEMENTS}

We wish to thank Prof. W. Pott (University of Hannover), Prof. S. Staśko (University of Wrocław), Dr. D. Remy (University of Osnabrück) and Dr. R. Hrivnak (Slovak Academy of Sciences, Bratislava) for cooperation.

\section{LITERATURE CITED}

BALSBERG-PAHLSSON A. 1989. Toxicity of heavy metals $(\mathrm{Zn}, \mathrm{Cu}, \mathrm{Cd}, \mathrm{Pb})$ to vascular plants. Water, Air and Soil Pollutions 47: 287-319.

BRAUN-BLANQUET J. 1964. Pflanzensoziologie, Grundzüge der Vegetationskunde. Dritte Auflage. Springer Verlag, Wien-New York.

BURROWS C. 1990. Processes of vegetation change. Unwin $\mathrm{Hu}-$ man 12: 420-489.

DALE V.H., BEYELER S.C. 2001. Challenges in the development and use of ecological indicators. Ecological Indicators 1(1): 3-10.

DERSCH G. 1986. Zur Verbreitung der Callitriche-Arten (Wassersterne) in Niedersachsen. Gött. Flor. Rundbr. 20: 79-100

GRODZIŃSKA K., GODZIK B. 1991. Heavy metal and sulphur in mosses from southern Spitsbergen. Polar Res. 9(2): 133-140.

GRUBE H.J. 1975. Die Makrophytenvegetation der Fließgewässer in Süd-Niedersachsen und ihre Beziehungen zur Gewässerverschmutzung. Arch. Hydrobiol. Suppl. 45(4): 376-456.

GUTOWSKI A., HOFMAN G., LEUKART P., MELZER A. MOLLENHAUER M., SCMEDTJE U., SCHNEIDER S., TREMP H. 1998. Trophiekartierung von aufwuchs-und ma- 
krophytendominierten Fließgewässern. Informationsberichte des Bayerischen Landesamtes für Wasserwirtschaft 4: 1-501.

HAURY J., MULLER S. 1991. Variations écologiques et chorologiques de la végétation macrophytique des rivičres acides du Massif armoricain et des Vosges du Nord (France). Revue des sciences de l'eau 4: 463-482.

HORSKA-SCHWARZ S., SPAŁEK K. 2008. Characteristics of selected springs of Opole Silesia region. In: Chmielewski T.J. (ed.), The Structure and Functionning of Landscape Systems: Meta-analyses, models, theories and its applications. The Problems of Landscape Ecology 21, Wydawnictwo Print 6, Lublin, pp. 311-318. (in Polish with English summary)

HUNSAKER C.T. 1993. New concepts in environmental monitoring: the question of indicators. Science of the Total Environment Supplement 1: 77-96.

MATUSZKIEWICZ W. 2005. Przewodnik do oznaczania zbiorowiska roślinnych Polski. Wydawnictwo Naukowe PWN, Warszawa. (in Polish)

MIREK Z., PIĘKOŚ-MIRKOWA H., ZAJĄC A., ZAJĄC M. 2002. Flowering plants and pteridophytes of Poland - a checklist. In: Mirek Z. (ed.), Biodiversity of Poland 1, W. Szafer Institute of Botany, Polish Academy of Sciences, Kraków, p. 442.

MONSCHAU-DUDENHAUSEN K. 1982. Wasserpflanzen als Belastungsindikatoren in Fließgewässern dargestellt am Beispiel der Schwarzwaldflüsse Nagold und Alb. Beih. Veröff. Natursch. Landsch. Pfl. Baden-Württ. 28: 1-118.

MÜLLER T. 1962. Die Fluthahnenfußgesellschaften unserer Fließgewässer. Veröff. Landesst. Natursch. Landsch. Pfl. Baden-Württ. 30: 152-163.

MÜLLER T., GÖRS S. 1977. Klasse: Potamogetonetea R. Tx. et Preising 42. In: Oberdorfer E. (ed.). Süddeutsche Pflanzengesellschaften. Teil I. G. Fischer Verlag, Stuttgart-New York, pp. 88-118.

OBERDORFER E. 1957. Süddeutsche Pflanzengesellschaften. Pflanzensoziologie 10: 1-564.

OBERDORFER E. 1994. Pflanzensoziologische Exkursionsflora. 7 Aufl. Verl. Eugen Ulmer, Stuttgart.

PASSARGE H. 1996. Pflanzengesellschaften Nordostdeutschlands. I. Hydro- und Therophytosa. J. Cramer, Berlin-Stuttgart.

PAWŁOWSKI B. 1956. Distributio specierum generis Callitriche L. in Polonia et in terris adiacentibus. Fragm. Flor. Geobot. 2(1): 27-48. (in Polish)

PIETSCH W. 1983. Vegetationsverhältnisse im NSG "Jeggauer Moor". Natursch. arb. Naturkdl. Heimatforsch. Bez. Halle u. Magdebg. 20: 41-44.

POTT R. 1980. Die Wasser- und Sumpfvegetation eutropher Gewässer in der Westfälischen Bucht - Pflanzensoziologische und hydrochemische Untersuchungen. Abh. Westf. Mus. f. Naturk. 42(2): 1-156.
POTT R. 1983. Die Vegetationsabfolgen unterschiedlicher Gewässertypen Nordwestdeutschlands und ihre Abhängigkeit vom Nährstoffgehalt des Wassers. Phytocoenologia 11(3): 407-430.

POTT R. 1990. Grundzüge der Typologie, Genese und Ökologie von Fließgewässern Nordwestdeutschlands, Natur- und Landschaftskunde 26: 25-32, 55-62.

POTT R. 1995. Die Pflanzengesellschaften Deutschlands. 2 Aufl. Verl. E. Ulmer, Stuttgart.

RENNWALD E. (ed.). 2000. Rote Liste der Pflanzengesellschaften Deutschlands mit Anmerkungen zur Gefährdung. In: Rennwald E. (ed.), Verzeichnis und Rote Liste der Phlanzengesellschaften Deutschlands. Schr.-R.f. Vegetationskunde 35: 393-592.

RODWELL J.S. (ed.) 2000. British Plant Communities. Vol. 4. Aquatic communities, swamps and tall-herb fens. Cambridge University Press.

SCHILLER A., HUNSAKER C.T., KANE M.A., WOLFE A.K., DALE V.H., SUTER G.W., RUSSELL C.S., PION G., JENSEN M.H., KONAR V.C. 2001. Communicating ecological indicators to decision makers and the public. Conservation Ecology 5(1): 19.

SCHWABE A. 1987. Fluß- und bachbegleitende Pflanzengesellschaften und Vegetationkomplexe im Schwarzwald. Diss. Bot. 102: 1-368.

SCHWABE A. 1989. Vegetation complexes of flowing-water habitats and their importance for the differentiation of landscape units. Landscape Ecology 2(4): 237-253.

SHAW A.J., ALBRIGHT D.L. 1990. Potential for The Evolution of Heavy Metal Tolerances in Bryum argenteum a Moss. II. Generalized Tolerances Among Diverse Populations. The Bryologist 93(2): 187-192.

STAŚKO S. 1984. Hydrogeological description of some chosen springs of the Opole District, Materiały i Studia Opolskie 26 (52-53): 277-298. (in Polish with English summary)

STAŚKO S. 1992. Wody podziemne w węglanowych utworach triasu opolskiego. Prace geologiczno-mineralogiczne 32: 1-71. (in Polish)

WOLFF P. 1999. Vegetation und Ökologie der nährstoffarmen Fließgewässer der Pfalz. Pollichia-Buch 37: 1-125.

ZAJĄC A., ZAJĄC M. (eds). 2001. Distribution Atlas of Vascular Plants in Poland. Edited by Laboratory of Computer Chorology, Institute of Botany, Jagiellonian University, Cracow.

ZERBE J., ELBANOWSKA H., GRAMOWSKA H., ADAMCZEWSKA M., SOBSZYŃSKI T., KABACIŃSKI M., SIEPAK J. 1994. Ocena wpływu emisji fluoru i innych zanieczyszczeń na wody, roślinność i gleby na obszarze Wielkopolskiego Parku Narodowego i jego otuliny. In: Kozacki L. (ed.). Geoekosystem Wielkopolskiego Parku Narodowego jako obszaru chronionego podlegającego antropopresji. Bogucki Wydawnictwo Naukowe, Poznań, pp. 89-135. (in Polish) 